\title{
The Noggin Cove Formation: a Middle Ordovician back-arc basin deposit in northeastern Newfoundland
}

\author{
D.H. Johnston ${ }^{1}$, H. Williams ${ }^{2}$ and K.L. Currie ${ }^{3}$ \\ ${ }_{1}$ Department of Geology, University of New Brunswick, Fredericton, New Brunswick E3B 5A3, Canada \\ ${ }^{2}$ Department of Earth Sciences, Memorial University of Newfoundland, \\ St. John's, Newfoundland AIB 3X5, Canada \\ ${ }^{3}$ Continental Geoscience Division, Geological Survey of Canada, \\ 601 Booth Street, Ottowa, Ontario K1A 0E8, Canada
}

Date Received March 16, 1994

Date Accepted November 18, 1994

\begin{abstract}
The Noggin Cove Formation is the largest volcanic unit of the eastern Exploits Subzone. It is approximately $1 \mathrm{~km}$ thick and consists mainly of stratified mafic volcaniclastic rocks with subordinate pillowed basalt and black shale. Stratigraphic relationships and regional correlations indicate a Middle Ordovician age. The Carmanville Mélange and the distinctive Woody Island formation, with coticule layers and olistostromes, occur along the northern margin of the Noggin Cove Formation, and the formation is faulted against siltstone and shale of the Davidsville Group along its southern margin.

The Noggin Cove Formation underwent three periods of deformation: (1) $D_{1}$, early recumbent $F_{1}$ folding; (2) $D_{2}$, northeast-trending tight to isoclinal $F_{2}$ folding with pervasive axial planar cleavage $\left(S_{2}\right)$; and (3) $D_{3}$, open east-plunging $F_{3}$ folding of the regional $S_{2}$ cleavage. Regional greenschist facies metamorphism was locally followed by contact metamorphism related to intrusion of the Siluro-Devonian Frederickton, Rocky Bay and Aspen Cove plutons.

Facies distribution, ubiquitous vesicular clasts, and the volume of monomictic volcaniclastic rocks imply that the Noggin Cove Formation is an erosional marine volcaniclastic apron built up to the south of a shallow marine to subaerial evolving volcanic source. Back-arc geochemical affinities, coupled with lithology and stratigraphy, indicate a back-arc basin paleotectonic setting.
\end{abstract}

La formation de Noggin Cove est l'unité volcanique la plus importante de la sous-zone orientale d'Exploits. Elle a environ $1 \mathrm{~km}$ d'épaisseur et est principalement constituée de roches volcanoclastiques mafiques à l'intérieur d'ampélite et de basalte en coussinets sous-jacents. Les rapports stratigraphiques et les corrélations régionales révèlent qu'elle remonte à l'Ordovicien moyen. Le mélange Carmanville et la formation caractéristique de Woody Island, pourvus de couches de coticules et d'olitostromes, apparaissent le long de la limite septentrionale de la formation de Noggin Cove. La formation est par ailleurs faillée contre du microgrès et du schiste argileux du groupe de Davidsville le long de sa limite sud.

La formation de Noggin Cove a connu trois périodes de déformation : a) $\mathrm{D}_{1}$, le pli couché inférieur $\mathrm{F}_{1}$; b) $\mathrm{D}_{2}$, le pli serré à isoclinal $F_{2}$ avec clivage ardoisier axial pénétrant $\left(S_{2}\right)$ en direction nord-est; et $D_{3}$, le pli incliné vers l'est $F_{3}$ du clivage régional $\mathrm{S}_{2}$. Le métamorphisme du faciès de schiste vert régional a localement été suivi par un métamorphisme de contact relié à l'intrusion des plutons du Siluro-Dévonien de Frederikton, Rocky Bay et Aspen Cove.

La répartition des faciès, la grande fréquence des fragments vésiculaires et le volume de roches volcanoclastiques détritiques monominérales permettent de supposer que la formation de Noggin Cove est une étendue plate volcanoclastique maritime formée par érosion créée au sud d'une source volcanique peu profonde maritime à subaérienne en évolution. Les affinités géochimiques d'arrière-arc, conjuguées à la lithologie et à la stratigraphie, révèlent un cadre paléotectonique à bassin arrière-arc.

[Traduit par la rédaction]

\section{INTRODUCTION}

The Noggin Cove Formation is a distinctive volcaniclastic unit in the northeastern part of the Exploits Subzone of the Newfoundland Dunnage Zone (Williams et al., 1988; Fig. 1). Interest in this unit stems from its proximity to the eastern margin of the early Paleozoic Iapetus Ocean and its association with the enigmatic Carmanville Mélange. The present study was undertaken to define and map the lithologies of the Noggin Cove Formation, to establish relationships to adjacent units, in particular the Carmanville Mélange and Woody Island formation, and to collect representative samples for geochemical studies.
Because of their spatial relationship and lithologic affinity, volcanic and gabbroic blocks in the Carmanville Mélange were also sampled for geochemical comparisons. A more detailed account of this work is contained in Johnston (1993).

\section{General Geology}

\section{Previous work and interpretations}

The Noggin Cove Formation is outlined on the 1:250,000 map of the Botwood area (Williams, 1964) and the 1:50,000 map of the Carmanville area (Currie and Pajari, 1980). It was 


\section{DEVONIAN}

\section{Legend}

Aspen Cove Pluton: Biotite-
+
muscovite, quartz monzonite.

SILURLAN
+
Homogeneous tonalite with poikilitic biotite.

MIDDLE ORDOVICIAN

Hamilton Sound sequence

$1 / 1$

Woody Island formation: Siltstone and shale, minor sandstone with thin Mn-rich layers; slumps and olistostromes common.

conformable contact

Carmanville Melange: Sittstone, sandstone and mafic volcanic clasts in a black shale matrix.

conformable contact

a) Noggin Cove Formation: Volcaniclastic

ha rock, pillow lavas, massive lava, mafic signature, na- non-arc geochemical signature.

Thrust Fault

ORDOVICIAN- ARENIG

to CARADOCIAN

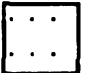

Davidsville Group: Siltstone, sandstone and shale; rare conglomerate.

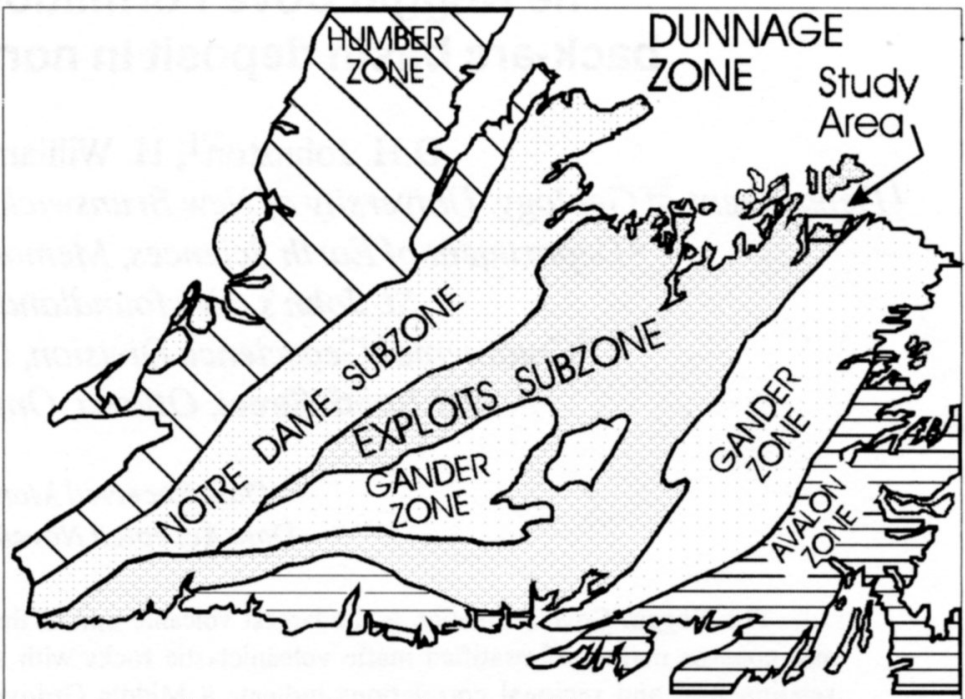

Newfoundland tectonostratigraphic zones/subzones

Symbols

(PD) pillow

(LF) lava flow,

(MD) mafic

(BS) Black

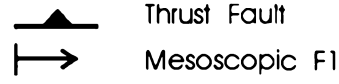

$\longleftrightarrow$ Mesoscopic F2

$\mathrm{H} \rightarrow \quad$ Mesoscopic F3 folds

Bedding, tops known: inclined, vertical, overturned Bedding, tops unknown: inclined, vertical

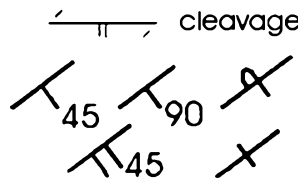

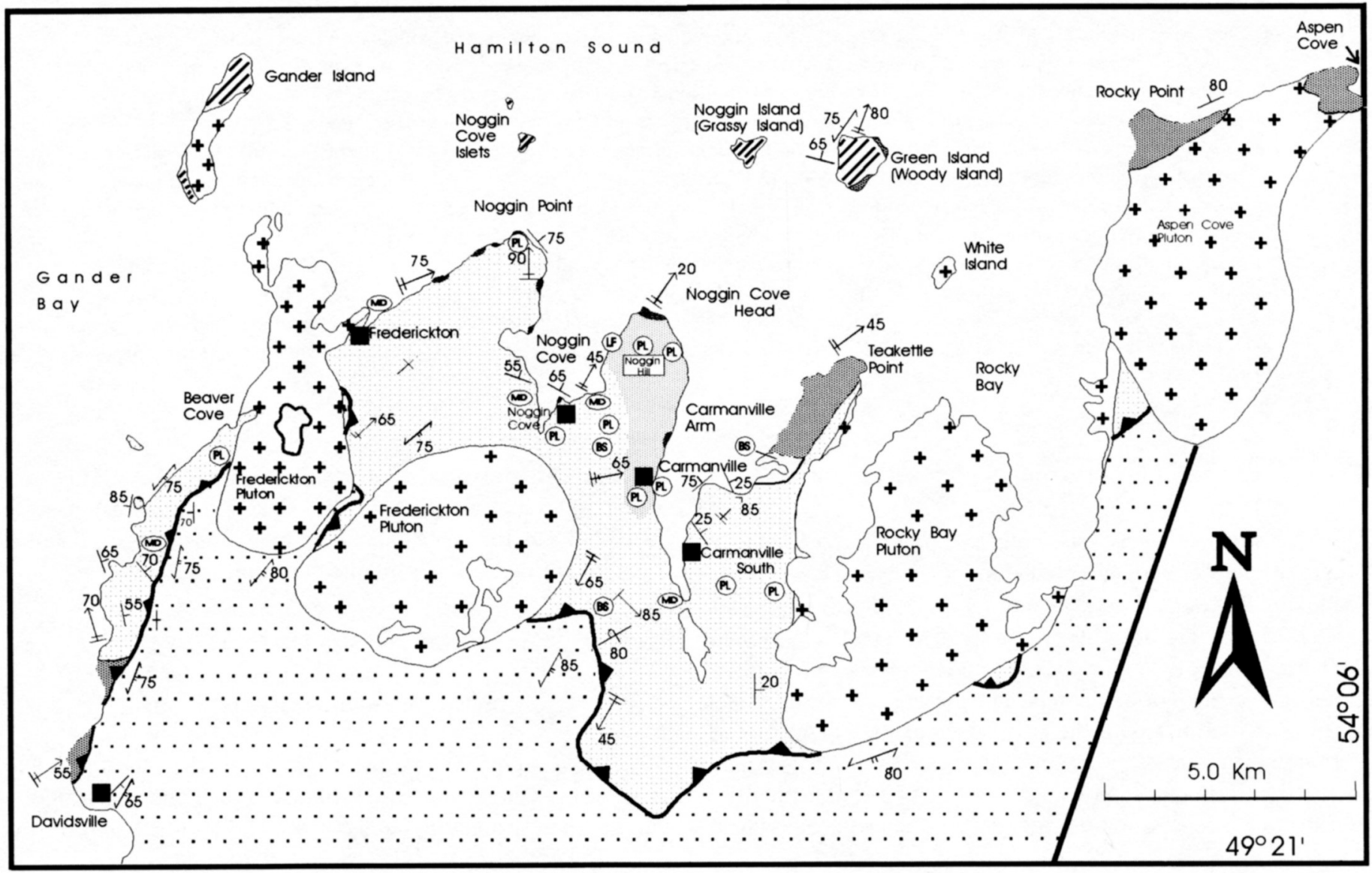

Fig. 1. Geological map of the Carmanville area. Inset map modified after Williams et al. (1988) 
also described or mentioned in the regional studies of Williams (1972), Kennedy and McGonigal (1972), Pajari et al. (1979), Pickerill et al. (1981), Williams et al. (1991), Currie (1992) and Johnston $(1992,1993)$. Early workers regarded the Noggin Cove Formation as a stratigraphic unit, first as part of the Gander Lake Group (Jenness, 1963; Williams, 1964) and later as part of the Davidsville Group (Kennedy and McGonigal, 1972). Discrete occurrences were also regarded as huge rafts in the Carmanville Mélange (Pajari et al., 1979) or erosional remnants of an allochthonous slice, emplacement of which may have controlled mélange formation along its periphery (Williams et al., 1991).

We formally propose the name Noggin Cove Formation, introduced by Williams et al. (1991), for two large areas of mafic volcanic rock which are separated by the Frederickton Pluton. The largest area is centred at Noggin Cove and a smaller area outcrops along the eastern shore of Gander Bay. Descriptions of the volcanic rocks, sedimentation, depositional environment, and classification were given previously, and the rocks referred to informally as the Carmanville volcanics (Pickerill et al., 1981).

\section{Regional setting}

The Noggin Cove Formation is associated with the Carmanville Mélange (Williams et al., 1991), which occurs mainly around its coastal periphery (Fig. 1). Siltstone and shale with distinctive coticule layers and coarse olistostromes, the informal Woody Island formation (Currie, 1992), are exposed on small islands in Hamilton Sound. The olistostromes of the Woody Island formation were considered part of the Carmanville Mélange by Pajari et al. (1979) and Williams et al. (1991). South of the study area, the Noggin Cove Formation is bordered by dark grey shale of the Davidsville Group, dated locally as Caradocian at Main Point on the eastern side of Gander Bay (Williams, 1972). The Noggin Cove Formation, Carmanville Mélange, and Woody Island formation were first grouped with these shales as part of the Davidsville Group (Kennedy and McGonigal, 1972). We follow Currie (1992, 1993) and assign the Noggin Cove Formation, Carmanville Mélange, and Woody Island formation to the informal Hamilton Sound sequence, and restrict the name Davidsville to rocks that overlie the Gander River Complex along the Exploits Subzone-Gander Zone boundary to the southeast (Blackwood, 1982; O'Neill and Blackwood, 1989; O'Neill, 1991). The contact between the Hamilton Sound sequence and Davidsville Group is poorly exposed; it is interpreted herein as a fault, with the Hamilton Sound sequence thrust southeast over the Davidsville Group (Fig. 1; see also Currie, 1992).

The Hamilton Sound sequence is unfossiliferous but lithologically similar to other Middle Ordovician groups and mélange tracts of the Exploits Subzone (Williams, 1992). Correlation of Ordovician strata westward across the Exploits Subzone is hindered by the recent discovery of the Dog Bay Line, a major Silurian transcurrent shear zone immediately northwest of the study area (Williams, 1993; Williams et al., 1993). The nearest correlative volcanic rocks to the west of the Dog Bay Line are the Loon Harbour volcanics (Currie, 1994). Caradocian interbedded pyritiferous and graphitic shale and chert conformably overlie the Loon Harbour volcanics; identical banded shale and chert occurs along the southern margin of the Noggin Cove Formation, but stratigraphic relations are unknown. On the west side of Gander Bay and east of the Dog Bay Line, the Silurian Indian Islands Group disconformably overlies the Hamilton Sound sequence (Williams, 1993).

The Siluro-Devonian Frederickton, Rocky Bay and Aspen Cove plutons (Pajari et al., 1979) separate discrete occurrences of the Noggin Cove Formation (Fig. 1). These plutons trend east-west and appear to have replaced an area approximately equal to the present occurrence of the Noggin Cove Formation. The base of the Noggin Cove Formation is not exposed. However, sections of the formation are hundreds of metres thick and their distribution implies a thickness of a kilometre or more.

\section{Lithology}

The Noggin Cove Formation consists of volcaniclastic conglomerate and sandstone, basaltic lavas, mafic dykes, bedded tuff, lapilli breccia, and minor black shale. Conglomerate forms approximately 65 to $75 \%$ of the formation. Basaltic lavas and mafic dykes constitute approximately 10 to $15 \%$, bedded tuffs about $10 \%$, lapilli breccias about $5 \%$, and black shales less than $5 \%$. Monotonous volcanic conglomerates in southern exposures (inland and Gander Bay shoreline) contrast with more variable volcaniclastic rocks exposed along northern shorelines (Fig. 2). A predominance of north-facing beds in the Noggin Cove Formation, and beds that face north on north-plunging secondphase folds along the northern shoreline from Frederickton to Carmanville South, imply that the variable lithologies are stratigraphically above the volcanic conglomerates.

Volcanic conglomerates are monomict with predominantly vesicular or amygdaloidal mafic clasts. Rare bulbous clasts have chilled margins. Clasts are poorly sorted, subangular to subrounded, and mainly between 1 and $30 \mathrm{~cm}$ in diameter (Fig. 3a). Clasts are supported in a fine to coarse tuffaceous matrix; only rarely are the conglomerates clast-supported. Within some beds there is chaotic mixing of clast-rich conglomerate and matrix-rich conglomerate. The conglomerate beds range from 15 $\mathrm{m}$ to less than a metre thick.

Clasts of bedded tuffs and recycled massive conglomerate are common. Boulder-sized clasts, up to $5 \mathrm{~m}$ in diameter, of folded, medium-bedded tuffs are also known, such as along the east shore of Gander Bay, $1 \mathrm{~km}$ north of Davidsville. Chaotic folding and contortion indicate soft-sediment deformation. Megablocks of massive conglomerate, up to $9 \mathrm{~m}$ in diameter, occur along the Carmanville South shoreline and on the western slope of the prominent ridge which overlooks this area (e.g., Fig. 3b).

Both normal and reverse grading occur in the coarser beds. Cross-bedding, scours, and grading in finer tuffs allow top determinations. Bottoms of beds are commonly planar, even where conglomerate overlies tuff. Parallel lamination of coarse-grained sandstone occurs in the upper and lower parts of some conglomerate beds. The long axes of ellipsoidal clasts commonly are oriented parallel to the contacts. Locally, clasts form crude bed-parallel layers and in rare cases are imbricated. 


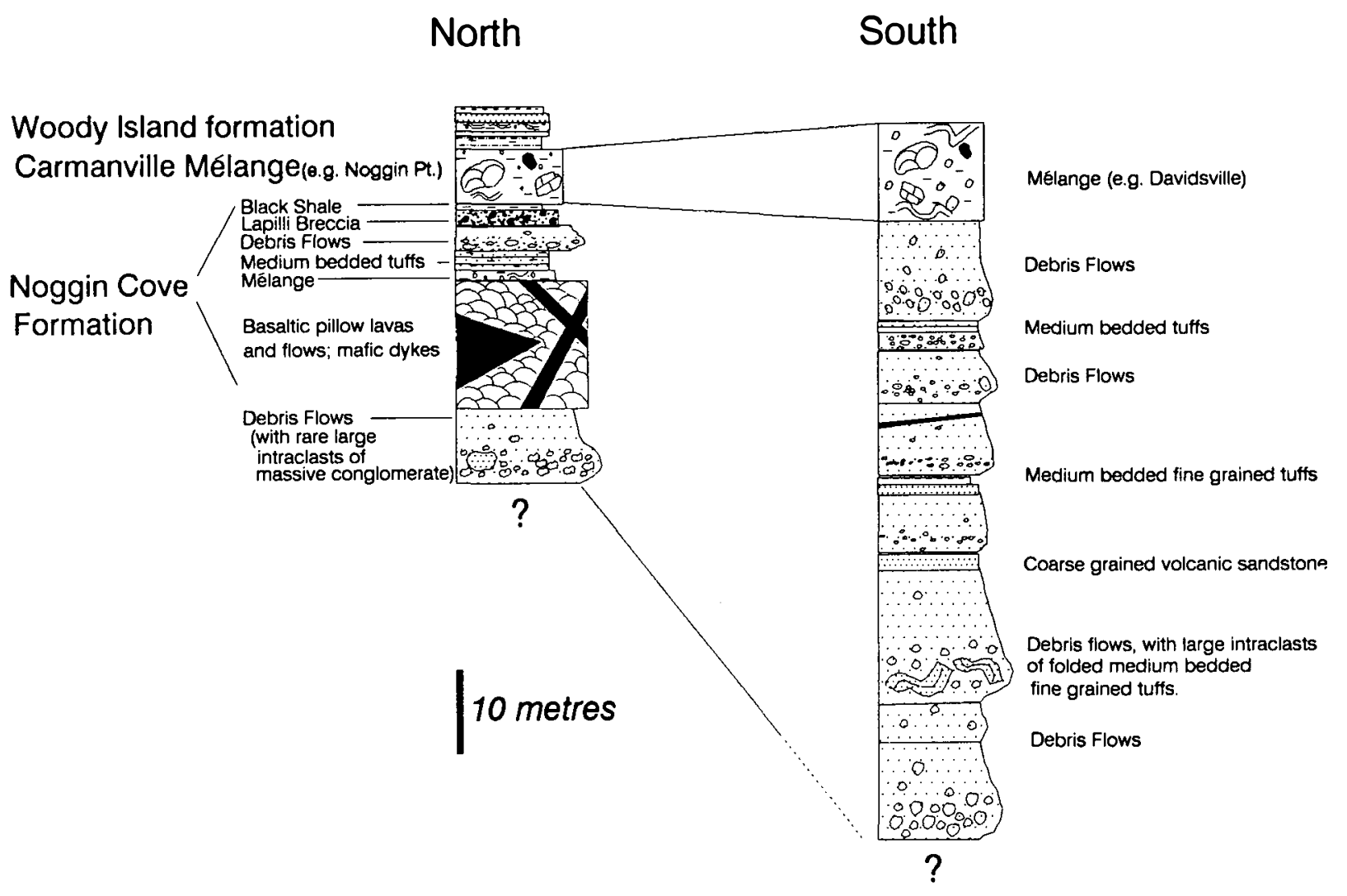

Fig. 2. Contrasting general stratigraphy for the north and south portions of the study area exposed at Noggin Cove (north) and along the Gander Bay shoreline (south). Debris flows are coarse conglomerate.

Basaltic pillowed and massive lava, and mafic dykes, are largely confined to northern exposures of the Noggin Cove Formation (Figs. 1, 2). The most extensive and largest outcrops occur from Noggin Hill southward to Carmanville and southwest into the town of Noggin Cove. Isolated smaller exposures occur just south of Beaver Cove, at Noggin Point, and in the hills east of Carmanville South. Pillow lavas and volcaniclastic rocks are locally interlayered.

Pillowed flows consist of dark green basalt with pillows up to $0.5 \mathrm{~m}$ in diameter. In general, the pillows are not amygdaloidal and are rimmed by dark selvages. Limestone commonly occurs interstitially with the pillows. A flow of massive lava occurs along the western side of Noggin Cove Head. Trondhjemite intruded this massive lava and trondhjemite occurs with pillow lava blocks in mélange at Noggin Cove Head and along the Carmanville shoreline. Small mafic dykes cut the flows and volcanic conglomerates. A larger dyke of picrite cuts conglomerate west of Noggin Cove.

Medium bedded, fine- to medium-grained reworked tuffs are largely confined to southern exposures of the Noggin Cove Formation, interbedded with the coarse volcanic conglomerates. A-C divisions of partial Bouma sequences in these tuffs are composed of normally graded, parallel-and cross-laminated deposits. Reverse grading is capped by normal grading in some beds. Some massive, pebbly coarse-grained sandstone beds are up to $1 \mathrm{~m}$ thick. Medium bedded, coarse-grained tuffs at Noggin Cove and Noggin Point are highly calcareous and locally exhibit low- to high-angle cross-bedding.
Lapilli breccias are confined to northern exposures at Frederickton, Noggin Point, on the southeastern shore of Noggin Cove, and in a large roadcut between Carmanville and Noggin Cove. The lapilli breccias consist of angular, dark basaltic clasts in a limey matrix. The same distinctive rock occurs as blocks in the Carmanville Mélange along the western shore of Noggin Cove and at Rocky Point. A chaotic breccia consisting of angular, finely bedded siltstone clasts in a limestone matrix is interbedded with lapilli breccia at Noggin Point and on the southeastern shore of Noggin Cove.

Minor occurrences of black shale are interbedded with volcanic conglomerates. The shales are graphitic, pyritic, and rustyweathering.

\section{Structure}

Three deformational events are recognized: an early phase $\left(\mathrm{F}_{1}\right)$ which predates the prominent northeast-trending regional cleavage $\left(\mathrm{S}_{2}\right)$, a second phase $\left(\mathrm{F}_{2}\right)$ of tight to isoclinal folds defined by the steeply southeast-dipping $S_{2}$ cleavage, and a third phase $\left(F_{3}\right)$ which folded the $S_{2}$ cleavage.

Mesoscopic $F_{1}$ folds are mainly tight to isoclinal, intrafolial, and attenuated or disrupted by the strong northeast-trending cleavage. Locally a weak bed-parallel cleavage is associated with $F_{1}$ folds. Coaxial $F_{1} / F_{2}$ fold interference patterns (type III of Ramsay, 1967) indicate that $F_{1}$ axial planes were at high angles to the steep $F_{2}$ axial planes, suggesting that $F_{1}$ folds were recumbent. Several examples of downward-facing structures and 


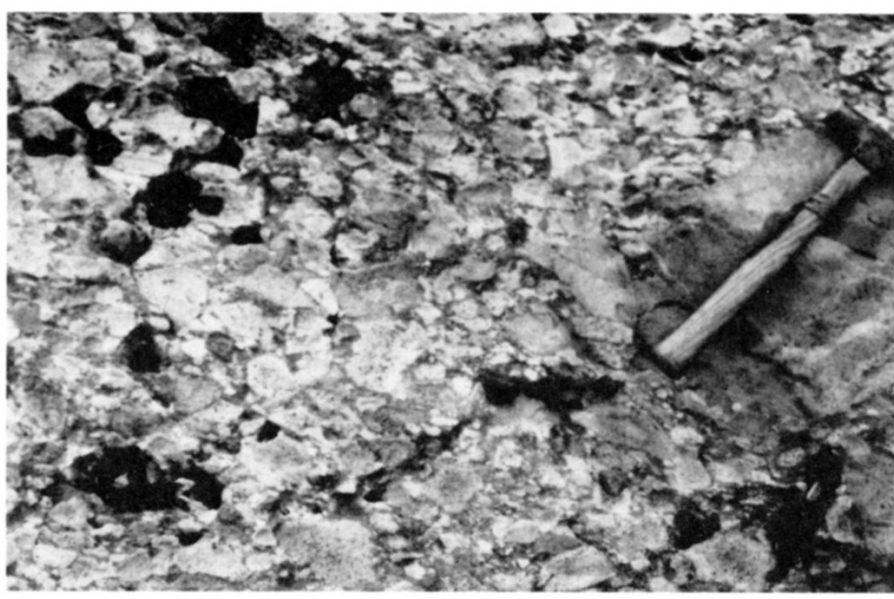

a

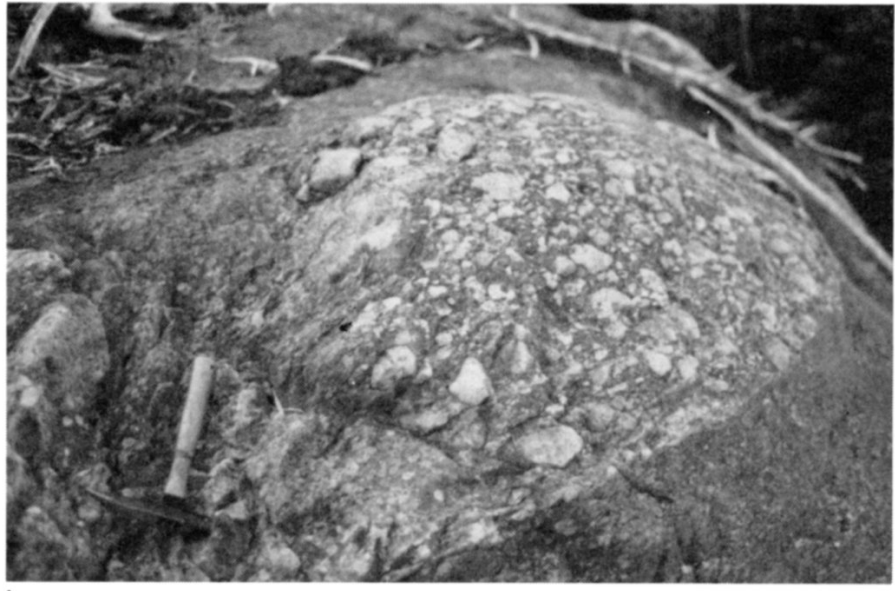

Fig. 3. (a) Clast-rich unsorted volcanic conglomerate of the Noggin Cove Formation, top of prominent knoll, southwest corner of Noggin Cove. Note the size of the clast under the hammer. (b) Large block of clast-rich, massive volcanic conglomerate in a more matrix-rich volcanic conglomerate, Noggin Cove Formation. Note the teardrop shape of the block; west slope of large hill overlooking Carmanville South.

overturned beds, cut by the steeper $\mathrm{S}_{2}$ cleavage, occur in the volcanic rocks south of Carmanville. Rare examples of steep overturned beds cut by a more shallow $S_{2}$ indicate that $F_{1}$ folds may have been asymmetrically inclined locally.

$\mathrm{S}_{2}$ cleavage is defined by the alignment of mica and amphibole and by the preferred orientation of elongate clasts. Asymmetric $F_{2}$ folds with variable plunges collectively form a girdle that matches the average orientation of $S_{2}$ (Johnston, 1993). Most $F_{2}$ folds plunge north to northeast, except for local southerly plunges southwest of Carmanville and at Davidsville. Detailed structural analysis of rocks that have undergone a similar deformational history west of Gander Bay indicates a sub-horizontal enveloping surface for macroscopic $\mathrm{F}_{2}$ folds (Karlstrom et al., 1982).

A weak, east-trending $S_{3}$ fracture cleavage is axial planar to open east-plunging $F_{3}$ folds; local south to southwest $F_{2}$ folds are attributed to this $\mathrm{F}_{3}$ folding.

\section{Metamorphism}

Rocks of the Noggin Cove Formation have undergone greenschist facies regional metamorphism. Few primary minerals remain; relict augite and plagioclase occur, and serpentinite psuedomorphs after olivine appear in a picrite dyke. Metamorphic minerals are calcic fibrous amphibole and subordinate chlorite, epidote, albite, sphene, calcite and biotite. Iron and titanium oxides are abundant. This regional metamorphism was associated with the $\mathrm{D}_{2}$ deformation and increases in grade eastward across the Carmanville area to amphibolite facies near the Dunnage/Gander boundary (Pajari and Currie, 1978).

The Noggin Cove Formation and nearby rocks are hornfelsed in the aureoles of the Frederickton, Rocky Bay and Aspen Cove plutons. Garnet and andalusite are developed in matrix shale of the Carmanville Mellange near the contact with the Rocky Bay Pluton. Two stages of amphibole growth in rocks of the Noggin Cove Formation indicate that contact metamorphism overprinted regional metamorphism. Fibrous tremolite, attributed to regional metamorphism, is overprinted by prismatic edenite attributed to contact metamorphism. The widespread occurrence of edenite and granitic dykes well away from the borders of the larger plutons suggests that the Noggin Cove Formation is a thin carapace above plutons that may be much larger at depth.

\section{Relations to nearby units}

Intense $\mathrm{D}_{2}$ deformation and absence of complete stratigraphic sections obscure relationships between the Noggin Cove Formation and the Carmanville Mélange and Woody Island formation. Lithic associations, predominance of facings in refolded beds, and regional relationships suggest a stratigraphic sequence consisting of the Noggin Cove Formation below the Carmanville Mélange, which is in turn overlain by the Woody Island formation (Fig. 2). This stratigraphic succession implies an original olistostromal Carmanville Mélange that was later tectonized.

An olistostromal origin for the Carmanville Mélange is also supported by the following: (1) bedded olistostromes occur at Beaver Cove, Noggin Cove, and Rocky Point; (2) olistostrome is interbedded and infolded with the Noggin Cove Formation along the western and southeastern shores of Noggin Cove; (3) intact, thin bedded siltstone occurs in the mélange matrix in shoreline exposures north of Davidsville, northeast of Frederickton and in Noggin Cove; and (4) thick olistostromes are interbedded with siltstones of the Woody Island formation at Woody Island and Noggin Cove Islets (Williams et al., 1991). The Carmanville Mélange at Davidsville is interpreted also as an olistostrome because: (1) the black shale matrix and clasts are identical to olistostromal mélange north of the Noggin Cove Formation; (2) sparse folded beds of siltstone occur within the mélange matrix; (3) coticule layers like those of the Woody Island formation occur in a large siltstone block in mélange along the shoreline at Davidsville; and (4) the enveloping surface of macroscopic $\mathrm{F}_{2}$ folds is subhorizontal (Karlstrom et al., 1982), suggesting horizontal layering prior to $F_{2}$. Thus the mélange at Davidsville may be a pre- $\mathrm{F}_{2}$ lateral equivalent of the mélanges north of the Noggin Cove Formation, now separated by $F_{2} / F_{3}$ folding and erosion.

The basaltic Noggin Cove Formation is distinctly monomictic ( $>95 \%$ mafic volcanic clasts) and does not contain clasts or beds of homogenized black shale or siltstone of the 
Carmanville Mélange. In contrast, the Carmanville Mélange contains blocks of all Noggin Cove Formation lithologies: pillow lava, bedded tuffs, massive conglomerate, lapilli breccia, massive gabbro, trondhjemite and limestone. This suggests that olistostromal deposition of the Carmanville Mélange succeeded the Noggin Cove Formation and that all mafic, trondhjemite and limestone blocks in the mélange could be derived from the Noggin Cove Formation.

Relationships between the Noggin Cove Formation and mélange at Teakettle Point are uncertain. This mélange seems to be above or laterally equivalent to the Noggin Cove Formation, but deformed black shales obscure the relationship so that a tectonic contact is also possible.

$F_{2}$ folds with low to moderate northeast plunges and consistent north-facing beds along the northern periphery of the Noggin Cove Formation imply that the mélanges along the shoreline and siltstones offshore are stratigraphically above the Noggin Cove Formation. The Silurian Indian Islands Group occurs farther north. This regional pattern implies a south to north progression of successively younger units, namely, Noggin Cove Formation, Carmanville Mélange, Woody Island formation, and Indian Islands Group.

Locally, the Noggin Cove Formation is in direct contact with the Woody Island formation. Siltstone, similar to that of the Woody Island formation, is in stratigraphic contact with volcanic conglomerate along the Frederickton to Noggin Point shoreline and with coarse-grained tuff in Noggin Cove. Coticule layers of fine-grained spessartine garnet and quartz, common in the Woody Island formation, also occur in siltstone and sandstone interbedded with volcaniclastic rocks of the Noggin Cove Formation at Beaver Cove.

An inferred fault contact between volcanic rocks of the Noggin Cove Formation and sandstone, siltstone and shale of the Davidsville Group is based on: (1) a sharp contact occurs between mafic volcanic conglomerates of the Noggin Cove Formation and the Davidsville Group (e.g., $1.0 \mathrm{~km}$ south of Beaver Cove just west of the road), (2) the Davidsville Group sedimentary rocks are invariably disrupted or sheared near the inferred contact, (3) the sinuous trace of the contact suggests it is an early thrust folded by $F_{2}$ (see also Karlstrom et al., 1982; O'Brien, 1993), (4) contoured gravity data show a pronounced east-west break along the southern margin of the Noggin Cove Formation (Miller, 1988), and (5) the local presence of banded slate and chert at the contact is similar in appearance and map pattern to the faulted slivers of Caradoc units elsewhere in the Exploits Subzone (B.H. O'Brien, personal communication, 1994).

\section{Geochemistry of the Noggin Cove Formation}

The Noggin Cove Formation consists predominantly of volcaniclastic rocks with subordinate flows. Clasts in the volcaniclastic rocks appear petrographically identical to flows. In addition, many large volcanic blocks within the Carmanville Mélange have generally been assumed to be derived from the Noggin Cove Formation. In order to characterize the Noggin Cove Formation and assess the provenance of clasts in the volcaniclastic rocks, 18 samples of various mafic volcanic rocks from the Noggin Cove Formation have been chemically analyzed; 7 are pillow lavas, 1 is a massive lava flow, 3 are mafic dykes, and 7 are volcaniclastic rocks. Of the 7 volcaniclastic rocks, 2 are fine-grained tuffs, 2 are coarse- to very coarsegrained volcaniclastic sandstones, and 3 are vesicular blocks that occur in coarse conglomerates. To characterize and assess the provenance of volcanic blocks in the Carmanville Mélange, 5 pillow lava and 2 massive gabbro blocks were also analyzed. Distinctive metabasite blocks that appear to be part of a more highly deformed and metamorphosed mélange (Williams et al., 1991) were not analyzed for this study. Sample descriptions, locations, analytical methods and results are given in Appendix 1.

Under greenschist facies metamorphic conditions, major elements are generally considered to be mobile (e.g., Hart et al., 1974). Therefore, the less mobile high-field-strength group of trace elements (P, Ti, Y, Zr, Nb, Hf, Ta; Saunders et al., 1980), Th (Wood et al., 1979), and rare earth elements (Shervais, 1982) are used for geochemical characterization and tectonic setting discrimination. Positive $\mathrm{Th}$ and negative $\mathrm{Nb}$ anomalies are the primary discriminants between arc and non-arc volcanic rocks (Wood, 1980; Arculus, 1987; Swinden et al., 1990)

On a $\mathrm{Zr} / \mathrm{TiO}_{2}$ vs $\mathrm{Nb} / \mathrm{Y}$ diagram (Fig. 4), most analyses plot in the subalkaline basalt field. This includes all analyses of lava blocks from the Carmanville Mélange, which overlap analyses of pillow lavas and mafic dykes of the Noggin Cove Formation. A minority of the analyses, including all the volcaniclastic rocks, cross the boundary into the alkaline basalt field. Gabbro blocks in the mélange lie to the extreme right and left in Figure 4; these coarse-grained gabbros are very likely cumulates and are therefore omitted from subsequent discrimination diagrams.

On the $\mathrm{TiO}_{2}$ vs $\mathrm{FeO} * / \mathrm{MgO}$ diagram (Fig. 5), $\mathrm{TiO}_{2}$ increases with $\mathrm{FeO} * \mathrm{MgO}$, implying tholeiitic affinities. Although this diagram uses major element data, formation of such a linear trend by alteration is improbable. The Hf-Th-Nb diagram (Fig. 6 ) shows that both arc and non-arc basalts are present. The majority of samples plot within the E-MORB and N-MORB fields, with the volcaniclastic rocks tightly grouped in the EMORB field. This tight grouping reflects the monomictic nature of the volcaniclastic rocks.

Extended rare earth element (REE) plots are given in Figure 7. Two samples of pillow lava and a sample of a massive lava flow have similar arc signatures (Fig. 7a). The three samples are from the largest occurrence of mafic lavas in the Noggin Cove Formation, exposed in the immediate Carmanville area and northward to Noggin Cove Head. These samples are light REE (LREE)-depleted and have a distinctive positive Th/negative $\mathrm{Nb}$ anomaly. All other samples have non-arc signatures (Fig. 7b, c).

Thirteen of 25 samples, including all 7 volcaniclastic samples, are strongly LREE-enriched non-arc basalts (Fig. 7b). Eight samples have a weakly LREE-depleted non-arc basalt signature, including all 5 blocks of pillow lava from the Carmanville Mélange (Fig. 7c). Two samples from pillow lavas of the Noggin Cove Formation and a mafic dyke that cuts pillow lava also have this signature. 


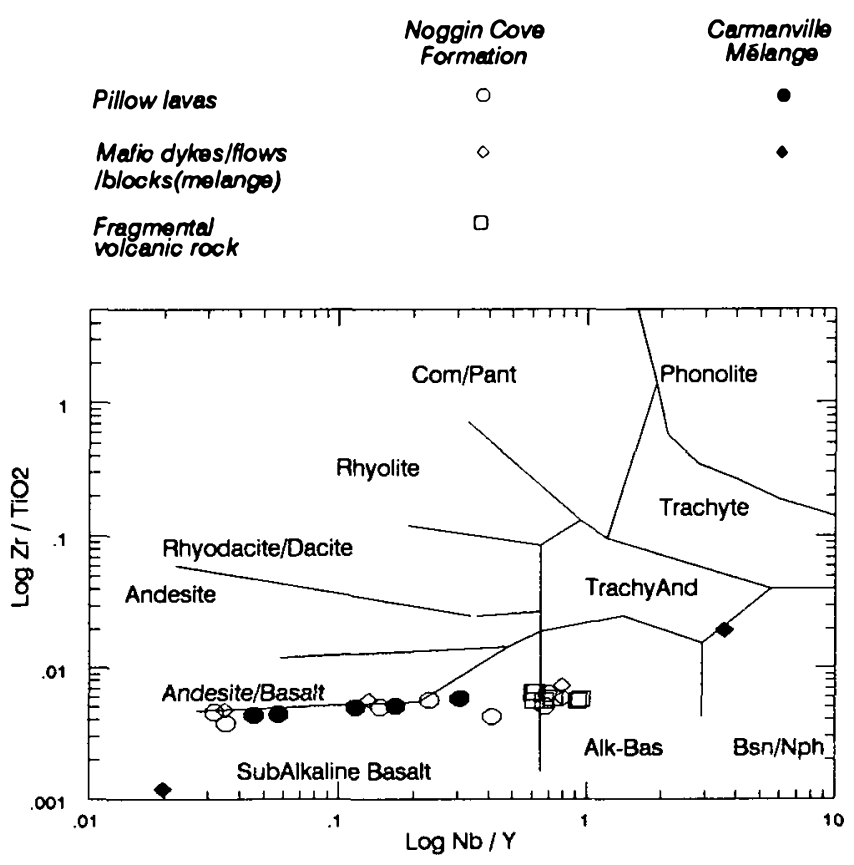

Fig. 4. $\mathrm{Zr} / \mathrm{TiO}_{2}$ versus $\mathrm{Nb} / \mathrm{Y}$ discrimination diagram (after Winchester and Floyd, 1977) for samples of volcanic rock from the Noggin Cove Formation and Carmanville Mélange. Symbols pertain to all subsequent diagrams to distinguish samples from the Noggin Cove Formation and Carmanville Mélange.

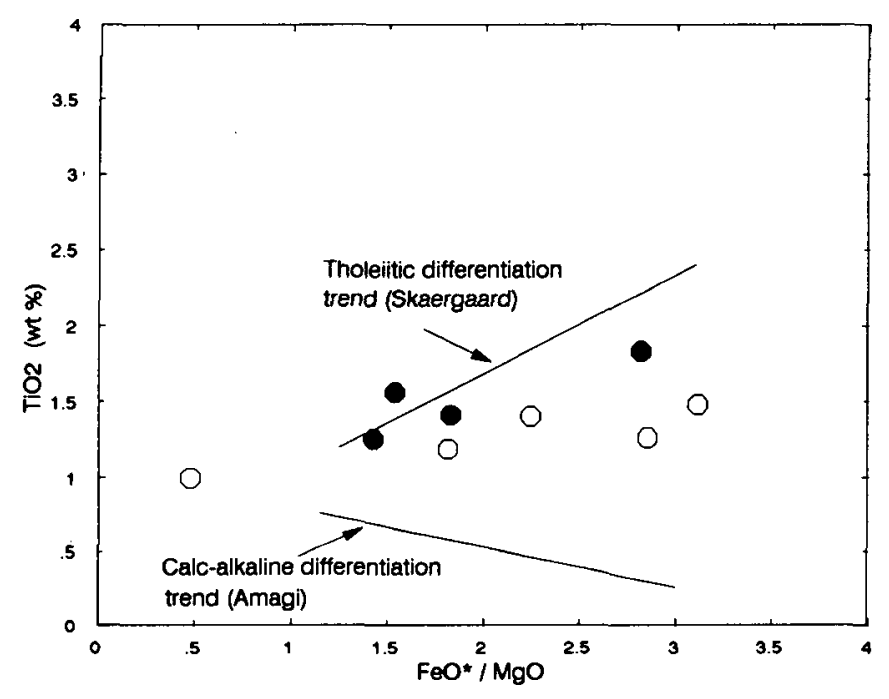

Fig. 5. $\mathrm{TiO}_{2}$ versus $\mathrm{FeO} * / \mathrm{MgO}$ discrimination diagram (after Miyashiro, 1974) for subalkaline basalts of Figure 4 . Symbols as in Figure 4.

\section{Interpretation of the Noggin Cove Formation}

The coarse volcanic conglomerates of the Noggin Cove Formation are its most diagnostic feature, some of which are spectacular in terms of their thickness and the size of massive and bedded intraclasts. The following features are consistent with deposition as subaqueous debris flows (Hampton, 1972; Fisher, 1984; Pickerill et al., 1981): (1) lack of sorting, (2) common occurrence of very large isolated clasts, (3) large blocks of bedded tuff and massive conglomerate, (3) clasts rimmed with ma-

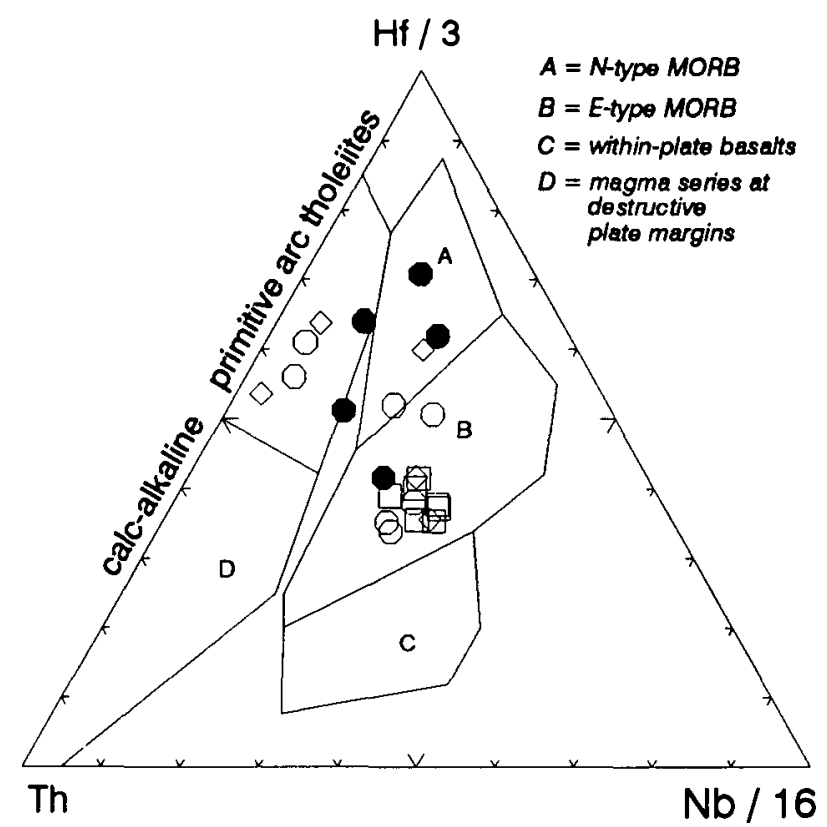

Fig. 6. Hf/3-Th-Nb/16 discrimination diagram (after Wood, 1980) for samples of volcanic rocks from the Noggin Cove Formation and Carmanville Mélange. Symbols as per Figure 4.

trix, (4) chaotic mixing of clast-rich and matrix-rich conglomerate within some beds, (5) parallel lamination in coarse-grained sandstones, (6) beds many times thicker than maximum clast size, (7) narrow zone of reverse grading at the base of many beds, and (8) thick cap of sandstone gradational with conglomerate in some beds.

The coarseness of the volcanic conglomerate indicates proximal deposition. Their association with proximal to medial turbidite, black shale, olistostromal mélange, and coticule layers of the Woody Island formation indicates marine conditions.

The high proportion of volcaniclastic rocks relative to flows, a predominance of volcanic and mafic clasts in these volcaniclastic rocks, the preponderance of vesicular clasts, the monomictic nature of the conglomerates, bulbous clasts with chilled margins, and the sheer volume of the volcaniclastic rocks are indicators of an explosive source (Garcia, 1978). Vesicular clasts indicate that the volcanic source was subaerial to shallow marine (empirically less than $200 \mathrm{~m}$ below sea level; Fisher, 1984).

The following features indicate that the volcanic source was located to the north of present exposures: (1) debris flow conglomerates dominate in southern outcrops whereas pillowed lavas, massive flows, and mafic dykes are predominant to the north; (2) a south to southwest paleoflow direction is indicated by imbricated clasts in local bedded tuffs at Noggin Cove; (3) clast-supported volcanic conglomerates and megablocks of massive conglomerate are more common in northern exposures; and (4) medium bedded cross-stratified calcareous tuff and lapilli breccia with a calcite matrix, interpreted as shallow marine deposits, occur only in northern exposures.

The thicknesses of many of the debris flow deposits of the Noggin Cove Formation are likely the result of storage of the 


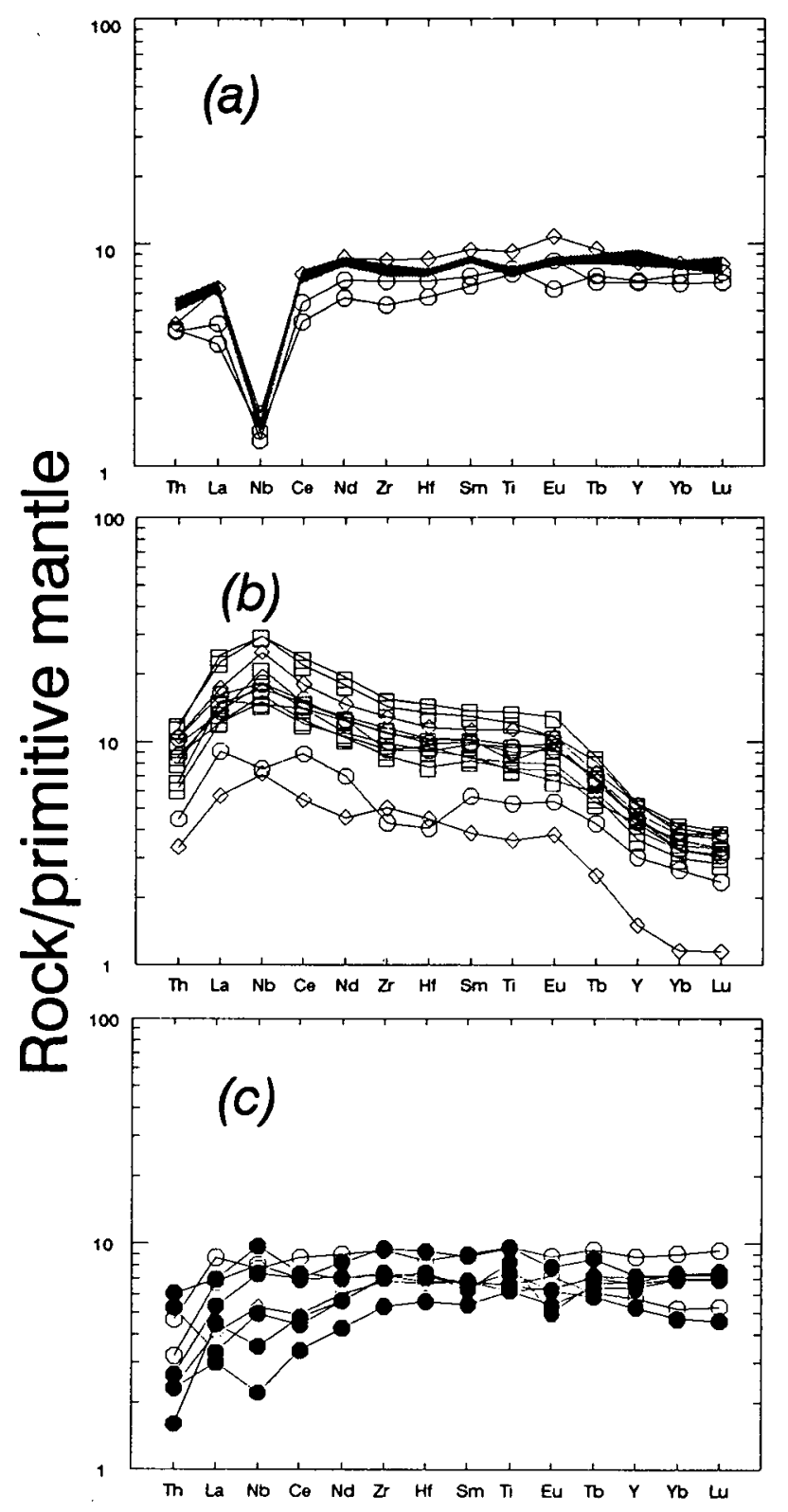

Fig. 7. Extended REE plots for volcanic rocks from the Carmanville area. Symbols as in Figure 4. Normalizing values from Swinden et al. (1990). (a) LREE-depleted, negative $\mathrm{Nb}$ anomaly. Stippled area is range of values for three samples dredged from the Valu Fa Ridge, an active back-arc spreading ridge in the Lau Basin of the South Pacific. (b) Strongly LREE-enriched, positive Nb anomaly. (c) Weakly LREE-depleted, positive $\mathrm{Nb}$ anomaly.

volcanic fragments on the slopes of a volcano, with release by earthquakes and/or gravitational instability. Bedded and massive intraclasts in volcanic conglomerates of the Noggin Cove Formation attest to lithification prior to disruption and resedimentation.

The change from monomictic mafic volcanic conglomerates of the Noggin Cove Formation to the polymictic Carmanville Mélange, and to the siliciclastic Woody Island formation, indicates a changing source and abrupt cessation of volcanism. The instability that controlled the volcanic debris flows apparently persisted as a control for olistostromes and slumped beds in the Carmanville Mélange and Woody Island formation.
Overlapping geochemical signatures for samples of volcanic rock from the Noggin Cove Formation and Carmanville Mélange suggest that all are from the same volcanic complex (Figs. 4, 5, 6, 7c). This overlap supports the contention that the exclusively non-arc mafic blocks in the mélange could be sourced from similar non-arc mafic rocks of the Noggin Cove Formation. A tight grouping of analyses of the monomictic volcaniclastic rocks in the E-MORB field (Fig. 4) reflects a persistent source.

Ocean island basalts, such as Kilauean tholeiites, are the nearest modern analogue to the non-arc LREE-enriched basalts of Figure $7 b$. However, basalts with REE patterns similar to this pattern are also found in some modern back-arc basins, such as the Lau Basin (Gill, 1976). The weakly LREE-depleted non-arc basalts of Figure $7 c$ are the most MORB-like, indicating little or no influence of a subducting slab on the source magmas. Modern equivalents of these basalts occur in back-arc basins, such as the Scotia Sea (Hawkesworth et al., 1977) and at transitional spreading portions of mid-ocean ridges ("TMORB" of Schilling et al., 1983). The coincidence and predominance of $\mathrm{N}$ - and E-MORB basalts suggests contemporaneous mid-ocean ridge and oceanic island volcanism (e.g., Iceland). However, the presence of basalts with arc signatures favours asthenospheric injection into a back-arc spreading ridge as a more likely scenario. There is an excellent match in the extended REE plots between the LREE-depleted arc basalts from the immediate Carmanville area and samples dredged from the Valu Fa Ridge (stippled area of Fig. 7a; Vallier et al., 1991). The Valu Fa ridge is an active back-arc spreading ridge in the Lau Basin, which separates the active Tofua volcanic arc from the Lau Ridge remnant arc (Tonga-Kermadec trend, South Pacific).

An overall arc setting is also indicated by the volume of volcaniclastic rock and its abundance relative to massive and pillowed lavas: arc volcanism is mainly explosive, whereas midocean ridge and oceanic island volcanism is predominantly effusive (Garcia, 1978).

The distinctive coticules (layers or nodules of quartz and spessartine garnet) of the Woody Island formation formed during low-grade metamorphism of these Mn-rich siltstones and shales. Concentrations of recycled dissolved $\mathrm{Mn}^{2+}$ could build up and be transported in anoxic seawater and precipitate subsequently in more oxygenated parts of a marginal basin (e.g., upper argillites and cherts of the Middle Ordovician Shoal Arm Formation, Exploits Subzone [Brüchert et al., 1994]). Alternatively, the Mn enrichment may have been hydrothermal and associated with sulphide deposition. Elemental analyses of over 180 samples from the Tonga-Kermadec Ridge and its marginal basins revealed $\mathrm{Mn}$ enrichment up to 10 times in the sediments of the Lau Basin (Cronan et al., 1984). Accumulation rates of $\mathrm{Mn}, 50 \mathrm{~km}$ west of the Lau Basin spreading ridge, approach those from hydrothermally active mid-ocean ridge crests, like the East Pacific Rise and Galapagos Rift that are characterized by hydrothermal $\mathrm{Mn}$ enrichment and sulphide deposition (Cronan et al., 1984). The Mn-rich, deep marine sedimentary rocks of the Woody Island formation are interpreted to have been deposited in a back-arc basin similar to the modern Lau Basin. 
The prolonged slumping required by the depositional model occurs more frequently on the arc flank of back-arc basins than in any other tectonic setting. This is the result of several factors, including steep regional gradients, high seismicity, rapid sediment accumulation, unstable thixotropic properties of sediment and shallow level intrusions into the sediments on steep slopes (Lonsdale, 1975; Busby-Spera, 1988).

Basaltic intra-plate volcanism such as ocean island basalt (OIB) and mid-ocean ridge basalt (MORB) that accompanied deposition of the Noggin Cove Formation volcaniclastic apron further supports an arc flank paleotectonic setting. Intra-plate volcanism is more common along the "hotter" arc flank than along the "colder" remnant arc flank of a back-arc basin (Weissel, 1981; Busby-Spera, 1988). OIB, MORB and arc volcanic rocks have been obtained from the arc flank of the Lau Basin (G. Jenner, personal communication, 1992).

The Noggin Cove Formation is interpreted, therefore, as a marine volcanic deposit dominated by proximal debris flows. The source was explosive, subaerial to shallow marine, and toward the present-day north. Lithologic, stratigraphic and geochemical evidence suggests volcanism and deposition along the arc flank of a back-arc basin. This setting is compatible with that of other coeval volcanic deposits in the Exploits Subzone of Newfoundland (Swinden et al., 1990).

The problems that remain unresolved in the Carmanville area offer exciting challenges for future work. The relationship of the large occurrence of arc lavas in the immediate Carmanville area (Fig. 1) to the rest of the Noggin Cove Formation needs to be better constrained. This relationship is critical in the determination of the tectonic setting of the Noggin Cove Formation. The arc lavas appear to be in place stratigraphically but more detailed geochemical and structural work is needed to ensure that it is not a fault-bounded sliver or a large block in mélange. Radiometric dating should accompany investigation of either of these possibilities and any future work in the Carmanville area.

\section{ACKNowledgements}

The authors thank the Natural Sciences and Engineering Research Council of Canada and the Geological Survey of Canada for supporting this research, and the people of Carmanville for their hospitality and humour. The first author extends special thanks to Drs. Toby Rivers, George Jenner and Brian O'Brien for their generous input and reviews.

ARCULUS, R.J. 1987. The significance of source versus process in the tectonic controls of magma genesis. Journal of Volcanology and Geothermal Research, 32, pp. 1-12.

BlackwOoD, R.F. 1982. Geology of the Gander Lake (2D/15) and Gander River (2EL2) area. Newfoundland Department of Mines and Energy, Mineral Development Division, Report 82-4, 56 p.

Brúchert, V., Delano, J.W., and Kidd, W.S.F. 1994. Fe- and Mn-enrichment in Middle Ordovician hematitic argillites preceeding black shale and flysch deposition: the Shoal Arm Formation, northcentral Newfoundland. Journal of Geology, 102, pp. 197-214.

BuCKLEY, D.E. and Cranston, R.E. 1968. Atomic absorption analysis of 18 elements from a single decomposition of aluminosilica. Marine Geology Atlantic Oceanographic Laboratory, Bedford Institute, Dartmouth, Nova Scotia.
BusBy-SPERA, C.J. 1988. Evolution of a Middle Jurassic back-arc basin, Cedros Island, Baja California: Evidence from a marine volcaniclastic apron. Geological Society of America Bulletin, 100, pp. 218-233.

Cronan, D.S., Moorby, S.A., Glasby, G.P., Knedler, K., Thomson, J., and Hodkinson, R. 1984. Hydrothermal and volcaniclastic sedimentation on the Tonga-Kermadec Ridge and in its adjacent marginal basins. In Marginal Basin Geology. Edited by B.P. Kokelar and M.F. Howells. Geological Society of London Special Publication No. 16, pp. 137-149.

CURRIE, K.L. 1992. Carmanville map area (2E-8): - a new look at Gander-Dunnage relations in Newfoundland. In Current Research, Part D, Geological Survey of Canada, Paper 92-1D, pp. 27-33.

- 1993. Ordovician-Silurian stratigraphy between Gander Bay and Birchy Bay, Newfoundland. In Current Research, Part D, Geological Survey of Canada, Paper 93-1A, pp. 11-18.

1994. Reconsidering parts of Comfort Cove and Gander River map areas, Dunnage Zone of Newfoundland. In Current Research, 1994-D, Geological Survey of Canada, pp. 33-40.

Currie, K.L. and Pajari, G.E. 1980. Geological map of Carmanville map area (2E/8), Newfoundland. Geological Survey of Canada, Open File 721

FISHER, R.V. 1984. Submarine Volcaniclastic Rocks. In Marginal Basin Geology. Edited by B.P. Kokelar and M.F. Howells. Geological Society of London Special Publication No. 16, pp. 5-27.

GARCIA, M.O. 1978. Criteria for the identification of ancient volcanic arcs. Earth Science Review, 14, pp. 147-165.

GiLl, J.B. 1976. Composition and age of Lau Basin and Ridge volcanic rocks: Implications for evolution of an interarc basin and remnant arc. Geological Society of America Bulletin, 87, pp. 13841395.

Hampton, M.A. 1972. The role of subaqueous debris flows in generating turbidity currents. Journal of Sedimentary Petrology, 42, pp. 775-793.

Hart, S.R., ERlank, A.J., and Kable, E.J.D. 1974. Sea floor basalt alteration: some chemical and $\mathrm{Sr}$-isotopic effects. Contributions to Mineralogy and Petrology, 44, pp. 219-230.

Hawkesworth, C.J., O’Nıons, R.K., Pankhurst, R.J., Hamilton, P.J., and Evenson, N.M. 1977. A geochemical study of island arc and back-arc tholeiites from the Scotia Sea. Earth and Planetary Science Letters, 36, pp. 253-262.

Jenness, S.E. 1963. Terra Nova and Bonavista Bay map areas, Newfoundland. Geological Survey of Canada, Memoir 327, 184 p.

Johnston, D.H. 1992. The Noggin Cove Formation, Carmanville map area, northeast Newfoundland; a back-arc basin volcanic complex. In Current Research, Part E, Geological Survey of Canada, Paper 92-1E, pp. 249-257.

1993. The Noggin Cove Formation and Carmanville Mélange: island arc rifting in northeast Newfoundland. M.Sc. thesis, Memorial University of Newfoundland, St. John's, Newfoundland, $210 \mathrm{p}$.

Karlstrom, K.E., van der Pluijm, B.A., and Williams, P.F. 1982. Structural interpretation of the eastern Notre Dame Bay, Newfoundland: regional post-Middle Silurian thrusting and asymmetrical folding. Canadian Journal of Earth Sciences, 19, pp. 2325-2341.

Kennedy, M.J. and McGonigal, M.H. 1972. The Gander Lake and Davidsville groups of northeastern Newfoundland: new data and geotectonic implications. Canadian Journal of Earth Sciences, 9, pp. $452-459$.

LANGmYhyr, F.J. and Paus, P.E. 1968. Analysis of silicate rocks. Analytical Chemica Acta, 43, pp. 397-408.

Longerich, H.P., Jenner, G.A., Fryer, B.J., and Jackson, S.E. 1990. Inductively coupled plasma-mass spectrometric analysis of geological samples: A critical evaluation based on case studies. In Microanalytical methods in mineralogy and geochemistry. Edited 
by P.J. Potts, C. Dupuy and J.F.W. Bowles. Chemical Geology, 83, pp. 105-118.

LONSDALE, P.F. 1975. Sedimentation and tectonic modification of the Samoan archipelagic apron. American Society of Petroleum Geologists Bulletin, 59, pp. 780-798.

MilleR, H.G. 1988. Geophysical interpretation of the geology of the northeast Gander Terrane, Newfoundland. Canadian Journal of Earth Sciences, 25, pp. 1161-1174.

Miyashiro, A. 1974. Volcanic rock series in island arcs and active continental margins. American Journal of Science, 274, pp. 321-355.

O'Brien, B.H. 1993. A mappers guide to Notre Dame Bay's folded thrusts: evolution and regional development. Newfoundland Geological Survey, Report 93-1, pp. 279-292.

O'NeILL, P.P. 1991. Geology of the Weir's Pond area, Newfoundland (NTS 2E/1). Newfoundland Department of Mines and Energy, Geological Survey Branch, Report 91-3, 144 p.

O'NeILl, P.P. and BlaCkwOOD, R.F. 1989. A proposal for revised stratigraphic nomenclature of the Gander and Davidsville groups and the Gander River ultrabasic belt of northeast Newfoundland. In Current Research. Edited by C.P.G. Pereira, D. Walsh and R.F. Blackwood. Newfoundland Department of Mines, Mineral Development Division, Report 89-1, pp. 127-130.

Pajari, G.E. and CURRIE, K.L. 1978. The Gander Lake and Davidsville groups of northeastern Newfoundland: a re-examination. Canadian Journal of Earth Sciences, 15, pp. 708-714.

Pajari, G.E., Pickerill, R.K., and Currie, K.L. 1979. The nature, origin and significance of the Carmanville Ophiolitic Mélange, Northeastern Newfoundland. Canadian Journal of Earth Sciences, 15, pp. 1439-1451

Pickerill, R.K., Pajari, G.E., and Currie, K.L. 1981. Resedimented volcaniclastics in the Carmanville area, northeastern Newfoundland - depositional remnants of early Paleozoic oceanic islands. Canadian Journal of Earth Science, 18, pp. 55-70.

RAMSAY, J.G. 1967. Folding and fracturing of rocks. McGraw-Hill Book Company, New York, $568 \mathrm{p}$.

Saunders, A.D., Tarney, J., Marsh, N.G., and Wood, D.A. 1980. Ophiolites as ocean crust of marginal basin crust: a geochemical approach. In Ophiolites. Proceedings of the International Ophiolite Symposium, Cyprus. Edited by A. Panayioutou. Cyprus Geological Survey Department, Ministry of Agriculture and Natural Resources, Nicosia, pp. 261-272.

Schilling, J-G., Zajac, M., Evans, R., Johnston, T., White, W., Devine, J.D., and Kingsley, R. 1983. Petrologic and geochemical variations along the mid-Atlantic Ridge from $29 \mathrm{~N}$ to $73 \mathrm{~N}$. American Journal of Science, 283, pp. 510-586.

Shervals, J.W. 1982. Ti-V plots and the petrogenesis of modern and ophiolitic lavas. Earth and Planetary Science Letters, 59, pp. 101118.

Swinden, H.C., Jenner, G.A., Fryer, B.J., Hertogen, J., and Roddick, J.C. 1990. Petrogenesis and paleotectonic history of the Wild Bight
Group, an Ordovician rifted island arc in central Newfoundland. Contributions to Mineralogy and Petrology, 105, pp. 219-241.

Vallier, T.L., Jenner, G.A., Frey, F.A., Gill, J.B., Davis, A.S., Volpe, A.M., Hawkins, J.W., MorRIS, J.D., Cawood, P.A., Moreton, J.L., Scholl, D.W., Rautenschlein, M., White, W.M., Williams, R.W., Stevenson, A.J., and White, L.D. 1991. Subalkaline andesite from Valu Fa Ridge, a back-arc spreading center in southern Lau Basin: petrogenesis, comparative chemistry, and tectonic implications. Chemical Geology, 91, pp. 227-256.

Weissel, J.K. 1981. Evolution of the Lau Basin by the growth of small plates. In Island arcs, deep sea trenches, and back-arc basins. Edited by M. Talwani and W. Pitman. American Geophysical Union Maurice Ewing Series, 1, pp. 429-436.

Williams, H. 1964. Botwood, Newfoundland. Geological Survey of Canada, Map 60-1963.

1972. Stratigraphy of Botwood map area, northeastern Newfoundland. Geological Survey of Canada, Open File 113, 117 p. - 1992. Mélanges and coticule occurrences in the northeast Exploits Subzone, Newfoundland. In Current Research, Part D, Geological Survey of Canada, Paper 92-1D, pp. 121-127.

1993. Stratigraphy and structure of the Botwood Belt and definition of the Dog Bay Line in northeastern Newfoundland. In Current Research, Part D, Geological Survey of Canada, Paper 93-1D, pp. 19-27.

Williams, H., Colman-Sadd, S.P., and Swinden, H.S. 1988. Tectonicstratigraphic subdivisions of Central Newfoundland. In Current Research, Part B, Geological Survey of Canada, Paper 88-1B, pp. 91-98.

Willlams, H., PiaseCki, M.A.J., and Johnston, D. 1991. The Carmanville Mélange and Dunnage-Gander relationships in northeast Newfoundland. In Current Research, Part D, Geological Survey of Canada, Paper 91-1D, pp. 15-23.

Willliams, H., Currie, K.L., and Piasecki, M.A.J. 1993. The Dog Bay Line - a major Silurian tectonic boundary in northeast Newfoundland. Canadian Journal of Earth Sciences, 30, pp. 2481-2494.

Winchester, J.A. and Floyd, P.A. 1977. Geochemical discrimination of different magma series and their differentiation products using immobile elements. Chemical Geology, 20, pp. 325-343.

WooD, D.A. 1980. The application of a Th-Hf-Ta diagram to problems of tectonomagmatic classification and to establishing the nature of crustal contamination of basaltic lavas of the British Tertiary Volcanic Province. Earth and Planetary Science Letters, 50, pp. 11-30.

Wood, D.A., Joron, J-L, and TreuIL, M. 1979. A re-appraisal of the use of trace elements to classify and discriminate between magma series erupted in different tectonic settings. Earth and Planetary Science Letters, 50, pp. 326-336.

Editorial responsibility : S.M. Barr

\section{Appendix 1: Geochemical Data}

\section{Appendix 1.1 Description and location of samples}

M576 Pillow lava block, Carmanville Mélange; eastern shoreline of Carmanville Arm, $1.75 \mathrm{~km}$ southwest of Twillick Point, known locally as Teakettle Point.

M578 Mafic dyke cutting pillow lava (M580), Noggin Cove Formation; large roadcut between the towns of Carmanville and Noggin Cove (north side of road).

M579 Fine-grained tuff, Noggin Cove Formation; east shoreline of Gander Bay, $2.5 \mathrm{~km}$ southwest of Beaver Cove.
M580 Pillow lava, Noggin Cove Formation; large roadcut between the towns of Noggin Cove and Carmanville.

M581 Pillow lava block, Carmanville Mélange; west side of Teakettle Point, $0.75 \mathrm{~km}$ from Point.

M582 Pillow lava block, Carmanville Mélange; Noggin Point. M583 Mafic dyke, cutting volcanic conglomerates, Noggin Cove Formation; shoreline, southeast corner of Noggin Cove. 
M584 Pillow lava, Noggin Cove Formation; beside Carmanville School.

M585 Pillow lava, Noggin Cove Formation; south end of prominent ridge overlooking the town of Carmanville South, $0.3 \mathrm{~km}$ east of the head of Carmanville Arm.

M587 Massive lava, Noggin Cove Formation; east shoreline of Noggin Cove, $1 \mathrm{~km}$ south of Noggin Cove Head.

M588 Pillow lava, Noggin Cove Formation; roadcut, south side of road, in town of Noggin Cove, just east of the head of Noggin Cove.

M589 Vesicular clast from volcanic conglomerate, Noggin Cove Formation; top of prominent hill overlooking southwest corner of Noggin Cove.

M590 Vesicular clast from volcanic conglomerate, Noggin Cove Formation; Frederickton, behind (south of) houses $0.25 \mathrm{~km}$ south of Noggin Cove road T- junction.

M591 Picrite dyke, cutting volcanic conglomerates, Noggin Cove Formation; small hill overlooking sawmill in town of Noggin Cove.

M592 Coarse-grained volcanic sandstone, Noggin Cove Formation; behind prominent church at the head of Noggin Cove.

\section{Appendix 1.2 Sample collection and analysis}

To minimize the effects metamorphism, vesiculation and weathering, samples were taken from the interiors of pillow lavas and large mafic blocks in the volcaniclastic conglomerates and from the centres of mafic dykes and the massive lava flow. The fine- to coarse-grained tuffs were pulverized and clasts hand-picked to avoid inclusion of matrix in the sample.

Major elements were analyzed using atomic absorption
M593 Vesicular clast from volcanic conglomerate, Noggin Cove Formation; entrance to abandoned Fox Farm, just east of Frederickton.

M594 Fine-grained tuff, Noggin Cove Formation; southsoutheast shoreline of Noggin Cove.

M595 Pebbly coarse-grained volcanic sandstone, Noggin Cove Formation; Frederickton to Noggin Point shoreline, approximately $100 \mathrm{~m}$ beyond the last house.

M2099 Block of coarse-grained massive gabbro, Carmanville Mélange; shoreline, $0.5 \mathrm{~km}$ south-southwest of Rocky Point.

M2100 Pillow block, Carmanville Mélange; shoreline, 0.30 km east of Rocky Point.

M2102 Pillow lava, Noggin Cove Formation; $1.0 \mathrm{~km}$ east of the head of Carmanville Arm.

M2103 Pillow lava, Noggin Cove Formation; Communication Tower, Noggin Hill.

M2 104 Pillow lava, Noggin Cove Formation; roadcut, 0.4 km south of Beaver Cove.

M2105 Block of coarse-grained massive gabbro, Carmanville Mélange; shoreline, $1 \mathrm{~km}$ north of Davidsville.

M2106 Pillow lava block, Carmanville Mélange; shoreline, 0.7 $\mathrm{km}$ north of Davidsville

\section{Appendix 1.3 Geochemical data, Noggin Cove Formation and Carmanville Mélange}

In the following presentation of geochemical data, oxides are given in percent, trace elements in ppm:

\begin{tabular}{|c|c|c|c|c|c|c|c|c|c|c|c|c|c|}
\hline Sample & M576 & M578 & 719579 & M580 & M581 & M582 & M583 & M584 & M586 & M587 & M588 & M589 & M590 \\
\hline $\begin{array}{r}\mathrm{SiO} 2 \\
\mathrm{TiO} 2 \\
\mathrm{Al} 2 \mathrm{O} 3 \\
\mathrm{FeO} \\
\mathrm{Fe} 2 \mathrm{O} 3 \\
\mathrm{MnO} \\
\mathrm{MgO} \\
\mathrm{CaO} \\
\mathrm{Na} 2 \mathrm{O} \\
\mathrm{K} 2 \mathrm{O} \\
\mathrm{P} 2 \mathrm{O} 5 \\
\mathrm{LO} \\
\text { Total }\end{array}$ & $\begin{array}{r}50.80 \\
1.24 \\
15.40 \\
7.69 \\
1.40 \\
0.16 \\
6.28 \\
10.83 \\
4.62 \\
0.17 \\
0.13 \\
1.52 \\
100\end{array}$ & $\begin{array}{r}49.60 \\
1.14 \\
13.50 \\
10.93 \\
1.83 \\
0.19 \\
6.94 \\
6.99 \\
4.37 \\
0.22 \\
0.09 \\
3.08 \\
98.88\end{array}$ & $\begin{array}{r}40.00 \\
1.32 \\
8.74 \\
7.58 \\
1.57 \\
0.14 \\
12.60 \\
18.50 \\
1.65 \\
0.12 \\
0.15 \\
7.40 \\
99.77\end{array}$ & $\begin{array}{r}46.70 \\
1.18 \\
15.10 \\
5.39 \\
3.80 \\
0.12 \\
3.09 \\
13.08 \\
4.64 \\
0.29 \\
0.13 \\
5.57 \\
99.09\end{array}$ & $\begin{array}{r}48.00 \\
1.78 \\
15.70 \\
13.28 \\
1.50 \\
0.25 \\
5.19 \\
5.04 \\
4.09 \\
2.19 \\
0.15 \\
2.00 \\
99.17\end{array}$ & $\begin{array}{r}50.60 \\
1.36 \\
14.00 \\
10.97 \\
0.80 \\
0.18 \\
6.40 \\
7.91 \\
3.18 \\
0.66 \\
0.10 \\
2.55 \\
98.71\end{array}$ & $\begin{array}{r}50.80 \\
2.06 \\
11.70 \\
6.80 \\
2.02 \\
0.15 \\
8.09 \\
8.97 \\
5.00 \\
0.23 \\
0.17 \\
2.97 \\
98.96\end{array}$ & $\begin{array}{r}51.60 \\
1.36 \\
14.70 \\
11.44 \\
1.09 \\
0.19 \\
5.54 \\
6.15 \\
4.47 \\
0.19 \\
0.10 \\
2.57 \\
99.40\end{array}$ & $\begin{array}{r}71.60 \\
0.48 \\
10.90 \\
4.79 \\
0.37 \\
0.10 \\
3.06 \\
1.74 \\
4.89 \\
0.06 \\
0.05 \\
2.42 \\
100.56\end{array}$ & $\begin{array}{r}50.00 \\
1.67 \\
13.20 \\
10.89 \\
2.82 \\
0.23 \\
5.97 \\
4.30 \\
5.21 \\
0.11 \\
0.10 \\
4.33 \\
98.83\end{array}$ & $\begin{array}{r}50.00 \\
1.66 \\
11.90 \\
9.15 \\
1.80 \\
0.17 \\
10.98 \\
8.76 \\
3.24 \\
0.18 \\
0.15 \\
2.51 \\
100.50\end{array}$ & $\begin{array}{r}42.20 \\
1.32 \\
9.85 \\
6.58 \\
5.86 \\
0.16 \\
18.65 \\
8.14 \\
1.43 \\
0.20 \\
0.09 \\
5.21 \\
99.69\end{array}$ & $\begin{array}{r}53.30 \\
1.78 \\
13.30 \\
7.24 \\
1.77 \\
0.12 \\
8.09 \\
6.24 \\
5.27 \\
0.56 \\
0.15 \\
1.56 \\
99.38\end{array}$ \\
\hline $\begin{array}{r}\mathrm{K} \\
\mathrm{Ba} \\
\mathrm{Sr}\end{array}$ & $\begin{array}{r}1411 \\
85 \\
261\end{array}$ & $\begin{array}{r}1826 \\
89 \\
158\end{array}$ & $\begin{array}{r}996 \\
12 \\
267\end{array}$ & $\begin{array}{r}2407 \\
101 \\
220\end{array}$ & $\begin{array}{r}18180 \\
364 \\
217\end{array}$ & $\begin{array}{r}5479 \\
83 \\
192\end{array}$ & $\begin{array}{r}1909 \\
62 \\
187\end{array}$ & $\begin{array}{r}1577 \\
50 \\
210\end{array}$ & $\begin{array}{r}498 \\
19 \\
51\end{array}$ & $\begin{array}{r}913 \\
31 \\
113\end{array}$ & $\begin{array}{r}1494 \\
26 \\
219\end{array}$ & $\begin{array}{r}1660 \\
15 \\
62\end{array}$ & $\begin{array}{r}4649 \\
134 \\
186\end{array}$ \\
\hline $\begin{array}{c}\mathrm{Nb} \\
\mathrm{Hf} \\
\mathrm{Zr} \\
\mathrm{Ti} \\
\mathrm{Y} \\
\mathrm{Th}\end{array}$ & $\begin{array}{r}6.3 \\
1.98 \\
72 \\
7434 \\
20 \\
0.53\end{array}$ & $\begin{array}{r}3.3 \\
1.82 \\
65 \\
6834 \\
25 \\
0.20\end{array}$ & $\begin{array}{r}9.6 \\
1.99 \\
78 \\
7913 \\
15 \\
0.50\end{array}$ & $\begin{array}{r}4.9 \\
1.78 \\
67 \\
7074 \\
21 \\
0.27\end{array}$ & $\begin{array}{r}4.7 \\
2.55 \\
92 \\
10671 \\
28 \\
0.23\end{array}$ & $\begin{array}{r}3.1 \\
2.03 \\
67 \\
8153 \\
27 \\
0.45\end{array}$ & $\begin{array}{r}15.7 \\
3.12 \\
121 \\
12350 \\
20 \\
0.89\end{array}$ & $\begin{array}{r}0.9 \\
1.58 \\
51 \\
8153 \\
26 \\
0.36\end{array}$ & $\begin{array}{r}1.2 \\
3.86 \\
131 \\
2878 \\
33 \\
1.04\end{array}$ & $\begin{array}{r}1.1 \\
2.30 \\
79 \\
10012 \\
31 \\
0.37\end{array}$ & $\begin{array}{r}11.5 \\
2.70 \\
106 \\
9952 \\
17 \\
0.74\end{array}$ & $\begin{array}{r}9.0 \\
2.41 \\
90 \\
7913 \\
15 \\
0.55\end{array}$ & $\begin{array}{r}13.4 \\
282 \\
110 \\
10671 \\
18 \\
0.83\end{array}$ \\
\hline $\begin{array}{c}\mathrm{La} \\
\mathrm{Ce} \\
\mathrm{Pr} \\
\mathrm{Nd} \\
\mathrm{Sm} \\
\mathrm{Eu} \\
\mathrm{Gd} \\
\mathrm{Tb} \\
\mathrm{Dy} \\
\mathrm{Ho} \\
\mathrm{Er} \\
\mathrm{Tm} \\
\mathrm{Yb} \\
\mathrm{Lu}\end{array}$ & $\begin{array}{r}4.36 \\
11.66 \\
1.72 \\
8.43 \\
2.69 \\
0.93 \\
3.36 \\
0.57 \\
3.80 \\
0.79 \\
2.21 \\
0.32 \\
2.01 \\
0.30\end{array}$ & $\begin{array}{l}2.47 \\
7.52 \\
1.29 \\
7.11 \\
2.64 \\
0.93 \\
3.67 \\
0.67 \\
4.64 \\
1.01 \\
3.07 \\
0.44 \\
2.94 \\
0.45\end{array}$ & $\begin{array}{r}7.16 \\
18.32 \\
2.60 \\
11.56 \\
3.01 \\
1.02 \\
3.11 \\
0.48 \\
3.00 \\
0.58 \\
1.57 \\
0.21 \\
1.31 \\
0.19\end{array}$ & $\begin{array}{r}4.02 \\
10.46 \\
1.62 \\
8.06 \\
2.55 \\
1.01 \\
3.41 \\
0.56 \\
3.82 \\
0.82 \\
2.35 \\
0.33 \\
2.11 \\
0.33\end{array}$ & $\begin{array}{r}3.31 \\
10.94 \\
1.86 \\
9.82 \\
3.46 \\
1.16 \\
4.79 \\
0.82 \\
5.42 \\
1.12 \\
3.20 \\
0.47 \\
3.09 \\
0.47\end{array}$ & $\begin{array}{l}2.03 \\
6.84 \\
1.21 \\
6.61 \\
2.53 \\
0.91 \\
3.57 \\
0.68 \\
4.68 \\
1.05 \\
3.24 \\
0.46 \\
3.05 \\
0.47\end{array}$ & $\begin{array}{r}10.43 \\
27.60 \\
3.74 \\
17.05 \\
4.31 \\
1.51 \\
4.55 \\
0.68 \\
4.05 \\
0.78 \\
2.01 \\
0.27 \\
1.60 \\
0.24\end{array}$ & $\begin{array}{l}2.20 \\
6.98 \\
1.21 \\
6.78 \\
2.54 \\
1.24 \\
3.64 \\
0.64 \\
4.53 \\
1.00 \\
2.93 \\
0.43 \\
2.82 \\
0.43\end{array}$ & $\begin{array}{r}6.59 \\
17.60 \\
2.71 \\
13.11 \\
4.10 \\
0.88 \\
4.68 \\
0.90 \\
5.84 \\
1.31 \\
4.06 \\
0.61 \\
4.08 \\
0.61\end{array}$ & $\begin{array}{r}3.80 \\
11.16 \\
1.83 \\
10.02 \\
3.60 \\
1.55 \\
4.92 \\
0.88 \\
5.89 \\
1.28 \\
3.72 \\
0.55 \\
3.38 \\
0.51\end{array}$ & $\begin{array}{r}8.46 \\
22.10 \\
3.14 \\
14.64 \\
3.88 \\
1.35 \\
3.98 \\
0.65 \\
3.83 \\
0.73 \\
1.89 \\
0.25 \\
1.53 \\
0.21\end{array}$ & $\begin{array}{r}8.99 \\
21.15 \\
2.83 \\
12.46 \\
3.22 \\
0.95 \\
3.39 \\
0.55 \\
3.18 \\
0.63 \\
1.65 \\
0.22 \\
1.33 \\
0.19\end{array}$ & $\begin{array}{r}8.29 \\
23.25 \\
3.29 \\
15.15 \\
3.99 \\
1.36 \\
4.04 \\
0.66 \\
3.88 \\
0.76 \\
2.15 \\
0.29 \\
1.61 \\
0.24\end{array}$ \\
\hline
\end{tabular}


Appendix 1.3 continued.

\begin{tabular}{|c|c|c|c|c|c|c|c|c|c|c|c|c|}
\hline Sample & M591 & M592 & M593 & M594 & M595 & M2099 & M2100 & M2102 & M210 & M210 & M2105 & M2106 \\
\hline $\begin{array}{r}\mathrm{SiO} 2 \\
\mathrm{TiO} 2 \\
\mathrm{Al} 2 \mathrm{O} 3 \\
\mathrm{FeO} \\
\mathrm{Fe} 2 \mathrm{O} 3 \\
\mathrm{MnO} \\
\mathrm{MgO} \\
\mathrm{CaO} \\
\mathrm{Na2O} \\
\mathrm{K} 2 \mathrm{O} \\
\mathrm{P} 2 \mathrm{O} \\
\mathrm{LO} \\
\text { Total }\end{array}$ & $\begin{array}{r}47.40 \\
0.64 \\
5.09 \\
5.71 \\
3.82 \\
0.15 \\
22.69 \\
8.69 \\
0.14 \\
0.02 \\
0.06 \\
5.39 \\
99.80\end{array}$ & $\begin{array}{r}43.40 \\
1.44 \\
9.64 \\
9.48 \\
2.26 \\
0.17 \\
17.08 \\
9.69 \\
1.27 \\
0.08 \\
0.14 \\
3.88 \\
99.53\end{array}$ & $\begin{array}{r}45.80 \\
1.48 \\
9.91 \\
8.25 \\
3.07 \\
0.18 \\
14.59 \\
9.88 \\
2.16 \\
0.22 \\
0.14 \\
3.39 \\
99.07\end{array}$ & $\begin{array}{r}44.20 \\
2.44 \\
11.40 \\
10.14 \\
2.00 \\
0.18 \\
11.49 \\
10.34 \\
2.39 \\
0.34 \\
0.20 \\
4.24 \\
99.36\end{array}$ & $\begin{array}{r}41.60 \\
2.14 \\
10.80 \\
10.56 \\
1.42 \\
0.18 \\
11.15 \\
12.08 \\
2.34 \\
0.89 \\
0.18 \\
6.29 \\
99.63\end{array}$ & $\begin{array}{r}48.20 \\
1.58 \\
13.06 \\
14.34 \\
1.91 \\
0.21 \\
7.04 \\
8.86 \\
2.44 \\
0.19 \\
0.05 \\
2.04 \\
99.92\end{array}$ & $\begin{array}{r}44.50 \\
1.53 \\
16.53 \\
12.37 \\
1.57 \\
0.27 \\
9.32 \\
6.61 \\
2.68 \\
1.52 \\
0.14 \\
3.49 \\
100.53\end{array}$ & $\begin{array}{r}42.95 \\
0.94 \\
6.50 \\
9.78 \\
2.62 \\
0.17 \\
25.43 \\
5.49 \\
0.19 \\
0.04 \\
0.13 \\
5.12 \\
99.36\end{array}$ & $\begin{array}{r}50.90 \\
1.44 \\
16.16 \\
12.10 \\
1.60 \\
0.18 \\
4.35 \\
4.63 \\
5.32 \\
0.33 \\
0.10 \\
3.22 \\
100.33\end{array}$ & $\begin{array}{r}48.90 \\
1.85 \\
13.30 \\
13.20 \\
2.62 \\
0.25 \\
5.69 \\
9.31 \\
3.89 \\
0.39 \\
0.19 \\
1.61 \\
101.20\end{array}$ & $\begin{array}{r}44.70 \\
2.10 \\
14.72 \\
9.89 \\
0.88 \\
0.52 \\
12.92 \\
5.66 \\
1.35 \\
0.68 \\
0.68 \\
5.51 \\
99.61\end{array}$ & $\begin{array}{r}52.65 \\
1.02 \\
15.39 \\
11.53 \\
0.00 \\
0.62 \\
4.93 \\
8.33 \\
3.52 \\
0.20 \\
0.09 \\
1.79 \\
100.07\end{array}$ \\
\hline $\begin{array}{r}\mathrm{K} \\
\mathrm{Ba} \\
\mathrm{Sr}\end{array}$ & $\begin{array}{r}166 \\
3 \\
46\end{array}$ & $\begin{array}{r}664 \\
29 \\
123\end{array}$ & $\begin{array}{r}1826 \\
73 \\
233\end{array}$ & $\begin{array}{r}2822 \\
85 \\
141\end{array}$ & $\begin{array}{r}7388 \\
108 \\
166\end{array}$ & $\begin{array}{r}1577 \\
20 \\
140\end{array}$ & $\begin{array}{r}12618 \\
247 \\
220\end{array}$ & $\begin{array}{r}332 \\
5 \\
109\end{array}$ & $\begin{array}{r}2739 \\
40 \\
134\end{array}$ & $\begin{array}{r}3238 \\
95 \\
161\end{array}$ & $\begin{array}{r}5645 \\
251 \\
343\end{array}$ & $\begin{array}{r}1660 \\
77 \\
200\end{array}$ \\
\hline $\begin{array}{c}\mathrm{Nb} \\
\mathrm{Hf} \\
\mathrm{Zr} \\
\mathrm{Ti} \\
\mathrm{Y} \\
\mathrm{Th}\end{array}$ & $\begin{array}{r}4.4 \\
1.19 \\
46 \\
3837 \\
6 \\
0.28\end{array}$ & $\begin{array}{r}9.2 \\
2.52 \\
85 \\
8633 \\
13 \\
0.72\end{array}$ & $\begin{array}{r}10.7 \\
2.74 \\
101 \\
8873 \\
17 \\
0.68\end{array}$ & $\begin{array}{r}18.3 \\
3.90 \\
144 \\
14628 \\
20 \\
0.96\end{array}$ & $\begin{array}{r}18.0 \\
3.50 \\
131 \\
12829 \\
19 \\
0.98\end{array}$ & $\begin{array}{r}0.2 \\
0.64 \\
18 \\
9472 \\
15 \\
0.08\end{array}$ & $\begin{array}{r}2.3 \\
2.04 \\
69 \\
9172 \\
26 \\
0.14\end{array}$ & $\begin{array}{r}4.6 \\
1.08 \\
40 \\
5635 \\
11 \\
0.37\end{array}$ & $\begin{array}{r}0.8 \\
1.88 \\
66 \\
8633 \\
26 \\
0.35\end{array}$ & $\begin{array}{r}5.1 \\
2.38 \\
92 \\
11091 \\
34 \\
0.41\end{array}$ & $\begin{array}{r}80.7 \\
8.33 \\
409 \\
12589 \\
22 \\
6.80\end{array}$ & $\begin{array}{r}1.2 \\
1.35 \\
45 \\
6115 \\
22 \\
0.18\end{array}$ \\
\hline $\begin{array}{c}\text { La } \\
\mathrm{Ce} \\
\mathrm{Pr} \\
\mathrm{Nd} \\
\mathrm{Sm} \\
\mathrm{Eu} \\
\mathrm{Gd} \\
\mathrm{Tb} \\
\mathrm{Dy} \\
\mathrm{Ho} \\
\mathrm{Er} \\
\mathrm{Tm} \\
\mathrm{Yb} \\
\mathrm{Lu}\end{array}$ & $\begin{array}{l}3.39 \\
8.22 \\
1.10 \\
5.20 \\
1.46 \\
0.54 \\
1.48 \\
0.23 \\
1.37 \\
0.25 \\
0.64 \\
0.08 \\
0.47 \\
0.07\end{array}$ & $\begin{array}{r}7.28 \\
18.18 \\
2.55 \\
12.07 \\
3.19 \\
1.12 \\
3.26 \\
0.52 \\
3.06 \\
0.58 \\
1.60 \\
0.20 \\
1.22 \\
0.18 \\
\end{array}$ & $\begin{array}{r}8.91 \\
22.74 \\
3.18 \\
14.64 \\
3.86 \\
1.39 \\
3.89 \\
0.63 \\
3.76 \\
0.72 \\
1.90 \\
0.24 \\
1.41 \\
0.21 \\
\end{array}$ & $\begin{array}{r}14.54 \\
35.92 \\
4.93 \\
22.30 \\
5.26 \\
1.84 \\
4.83 \\
0.79 \\
4.61 \\
0.88 \\
2.25 \\
0.31 \\
1.74 \\
0.25 \\
\end{array}$ & $\begin{array}{r}13.41 \\
32.51 \\
4.48 \\
20.24 \\
4.84 \\
1.47 \\
4.33 \\
0.74 \\
4.26 \\
0.77 \\
2.07 \\
0.28 \\
1.64 \\
0.23\end{array}$ & $\begin{array}{l}0.90 \\
2.36 \\
0.47 \\
3.02 \\
1.33 \\
0.55 \\
2.06 \\
0.37 \\
2.64 \\
0.59 \\
1.77 \\
0.26 \\
1.68 \\
0.26\end{array}$ & $\begin{array}{l}2.76 \\
7.41 \\
1.25 \\
6.68 \\
2.47 \\
0.73 \\
3.80 \\
0.64 \\
4.43 \\
1.01 \\
3.06 \\
0.46 \\
3.11 \\
0.49\end{array}$ & $\begin{array}{r}5.35 \\
13.16 \\
1.73 \\
7.97 \\
2.13 \\
0.76 \\
2.63 \\
0.39 \\
2.29 \\
0.45 \\
1.22 \\
0.16 \\
1.08 \\
0.15\end{array}$ & $\begin{array}{l}2.72 \\
8.53 \\
1.42 \\
8.19 \\
2.82 \\
0.93 \\
4.08 \\
0.69 \\
4.76 \\
1.06 \\
3.23 \\
0.45 \\
3.09 \\
0.48\end{array}$ & $\begin{array}{r}5.52 \\
13.87 \\
2.09 \\
10.96 \\
3.62 \\
1.32 \\
5.26 \\
0.92 \\
6.25 \\
1.38 \\
4.18 \\
0.61 \\
3.93 \\
0.62\end{array}$ & $\begin{array}{r}53.43 \\
105.77 \\
11.85 \\
44.78 \\
8.15 \\
2.42 \\
6.81 \\
0.88 \\
4.67 \\
0.85 \\
2.31 \\
0.31 \\
1.73 \\
0.28\end{array}$ & $\begin{array}{l}1.65 \\
4.67 \\
0.79 \\
4.47 \\
1.87 \\
0.70 \\
2.93 \\
0.54 \\
3.80 \\
0.87 \\
2.62 \\
0.38 \\
2.61 \\
0.40\end{array}$ \\
\hline
\end{tabular}

